\title{
Diversity of social wasps (Hymenoptera, Vespidae) in Cerrado biome of the southern of the state of Minas Gerais, Brazil
}

\author{
Matheus H. Simões ${ }^{1,2}$, Mariana D. Cuozzo ${ }^{1} \&$ Fernando A. Frieiro-Costa $^{1}$
}

1. Setor de Ecologia, Centro Universitário de Lavras - Unilavras, Rua Padre José Poggel, 506, Centenário, 37200-000 Lavras, MG, Brasil. marianacuozzo@hotmail.com; ffrieiro@gmail.com

2. Current address: Setor de Zoologia, Departamento de Biologia, Universidade Federal de Lavras, Caixa Postal 3037,37200-000 Lavras, MG, Brasil. matsimoes@hotmail.com

\begin{abstract}
An inventory of social wasps in Cerrado biome of the southern of the state of Minas Gerais was performed. A comparison between field and Riparian Forest areas was made in relation to species richness; correlations between diversity, sample methods and environmental factors were conducted. A total of 32 species was registered and Polybia fastidiosuscula de Saussure, 1854 was the most abundant species. The higher richness was in the Cerrado Field, as well as the highest diversity index. The temperature and rainfall had significant correlation with species richness and a significant variation in richness between dry and wet seasons was observed. Polybia fastidiosuscula was more abundant in the Riparian Forest during the dry season and in the Cerrado Field during wet season. The study area showed a great diversity of social wasps, with record both widely distributed species such as rare species, which indicates the quality and potential area for future studies.
\end{abstract}

KEYWORDS. Polistinae, inventory, composition, seasonality.

RESUMO. Diversidade de vespas sociais (Hymenoptera, Vespidae) no Cerrado do sul do estado de Minas Gerais, Brasil. Foi realizado um inventário de vespas sociais em área do bioma Cerrado do sul do estado de Minas Gerais. Foram comparadas uma área de campo e uma área de mata ciliar em relação à riqueza de espécies, bem como verificadas as correlações entre diversidade, métodos de amostragem e os fatores ambientais. Um total de 32 espécies foi registrado e Polybia fastidiosuscula de Saussure, 1854 foi a espécie mais abundante. A maior riqueza foi registrada na área de campo, bem como o maior índice de diversidade. A temperatura e pluviosidade apresentaram correlação significativa com a riqueza de espécies e uma variação significativa na riqueza entre as estações seca e úmida foi observada. Polybia fastidiosuscula foi mais abundante na mata ciliar durante a estação seca e na área de campo na estação úmida. A área de estudo apresentou uma grande diversidade de vespas sociais, registrando tanto espécies amplamente distribuídas como espécies raras, o que indica a qualidade e o potencial da área para futuras pesquisas.

PALAVRAS-CHAVE. Polistinae, inventário, diversidade, sazonalidad.

The social wasps belong to the family Vespidae, which is divided into six subfamilies: Eumeninae, Masarinae and Euparagiinae (solitary species); Stenogastrinae (pre-social); and Vespinae and Polistinae (social wasps) (CARPENTER, 1982). The species found in Brazil belong to Polistinae and 21 of the 25 genera composing this subfamily are found in the Neotropical region (CARPENTER \& MARQues, 2001; CARPENTER, 2004).

Besides the importance of social wasps for understanding the evolution of social behavior, these insects are an ecologically important group. The high protein diet provides relevant ecological and economic roles in the biological control of pests (Рвеzото et al., 2007). Some species are necrophagous, and play a considerable role in nutrient cycling by accelerating this process (O’Donnell, 1995).

Due to ecological importance of social wasps, various studies have been conducted in order to better understand the biology of this group, involving aspects of preference for nesting habitat and nest density (DINIZ \& Kitayama, 1994), seasonality (Diniz \& Kitayama, 1998), nesting habits (Lima et al., 2000) or inventories. A significant number of species records have been carried out in the Amazon region (Silveira, 2002; Silveira et al., 2005; Silveira et al., 2008; Silva \& Silveira, 2009), Atlantic forest (SANTos et al., 2007; GomEs \& Noll, 2009) and Cerrado (Diniz \& Kitayama, 1994; Diniz \& Kitayama, 1998; Souza \& Prezoto, 2006; Elpino-Campos et al., 2007; Prezoto \& Clemente, 2010; Souza et al., 2010).
Biological inventories are the first step to be considered in conservation studies concerning environmentally relevant areas, since it is difficult to preserve what it is yet unknown (CULLEN JR et al., 2003). Inventories of social wasps are still quite scarce, although they have been increasing throughout the last decade. The southern of the state of Minas Gerais, Brazil, is a still unstudied region as to the diversity of social wasps. Thus, an inventory in a Cerrado biome area was undertaken comparing with others conducted in a Cerrado biome of state of Minas Gerais. A comparison between field and riparian forest areas was made in relation to species richness; correlations between diversity, sample methods and environmental factors were conducted.

\section{MATERIAL AND METHODS}

The study was performed in the Reserva Biológica Unilavras/Boqueirão, located in Ingaí, southern of the state of Minas Gerais, Brazil, between April 2009 and February 2010 in different phytophysiognomies. It is private property of the Centro Universitário de Lavras Unilavras, located at $21^{\circ} 20^{\prime} 47^{\prime \prime}$ S and $44^{\circ} 59^{\prime} 27^{\prime \prime} \mathrm{W}$. It has a total area of 160 ha in the Cerrado biome and an average altitude of 1,100 meters (Pereira \& Volpato, 2005).

Sampling was conducted through active search and attractive traps. The active search was performed with the aid of a hand net and focused on searching for colonies and foraging individuals along hiking trails and stream margins 
located in the study area. Attractive traps were prepared by using 2-liter PET bottles (Polyethylene Terephthalate bottles) with two triangular lateral openings (4 X 4 X 4 $\mathrm{cm}$ ) in the lower portion, approximately $10.0 \mathrm{~cm}$ from the base. Each bottle was filled with passion fruit juice or sardine broth to attract the wasps. The passion fruit juice was prepared with $500 \mathrm{ml}$ of concentrated fruit juice and $300 \mathrm{~g}$ of sugar for every 1.5 liters of water. The broth was prepared with one can of sardines (125 $\mathrm{g}$ of canned sardine in $1 \mathrm{~L}$ of tap water, modified of Souza \& Prezoto, 2006).

The study area was divided in two distinctive phytophysiognomies: Cerrado Field (corresponds to transition areas between Cerrado stricto sensu and Rupestrian field - Campo Rupestre) and Riparian Forest. The division of the area was performed to compare open field area and forest area. The attractive traps were then distributed along a 400-meter transect in each phytophysiognomy. Each transect was divided into 20 sampling stations (20 meters equidistant). Three traps were placed in each sampling station. All of the traps were filled with $200 \mathrm{ml}$ of the attractive substance: one filled with passion fruit juice, one filled with sardine and one filled with plain water (control group). All of the traps were attached to tree trunks at approximately 1.5 meters from the ground. These collections were performed monthly. The specimens collected were deposited in the invertebrate collection of the Centro Universitário de Lavras (Unilavras), Lavras, state of Minas Gerais, Brazil, where the sorting and separation of the species were performed.

The Jack-Knife richness estimator was used to estimate species richness in the study area, thus registering the percentage of species observed in relation to possible local richness. To compare differences among sampling methods and between the phytophysiognomies, was used the species capture frequency in the samples (Silveira, 2002) (considering high frequency species those that was recorded in $50 \%$ or more of the samples), Shannon-Wiener $\left(\mathrm{H}^{\prime}\right)$ diversity index (base 10 logarithms) and BergerParker dominance (DBP). The DivEs - Diversidade de Espécies program (RodRIGUes, 2007) was used for the calculation of indices.

To assess the normality of the data, the ShapiroWilk test was employed. To calculate the richness variance between dry and wet seasons, ANOVA test was performed. The richness was correlated with climatological data obtained from the Agrometereology Weather Station of Universidade Federal de Lavras (UFLA), Lavras, state of Minas Gerais, Brazil. To test correlation between these data, Spearman's Rank Correlation was used.

\section{RESULTS}

A total of 6,562 individuals of social wasps were recorded during this study and were distributed among 32 species belonging to 10 genera. Polybia
(Myrapetra) fastidiosuscula de Saussure, 1854, was the most abundant (93.4\%) and frequent species in the samples (Tab. I). Only two specimens were captured in the control group.

The rarefaction curve almost reached stability. Moreover, the Jack-Knife 1 species richness estimator showed that the richness in the study area should be 37-38 species (Fig. 1). So, the 32 species recorded corresponds to $85 \%$ of the estimate.

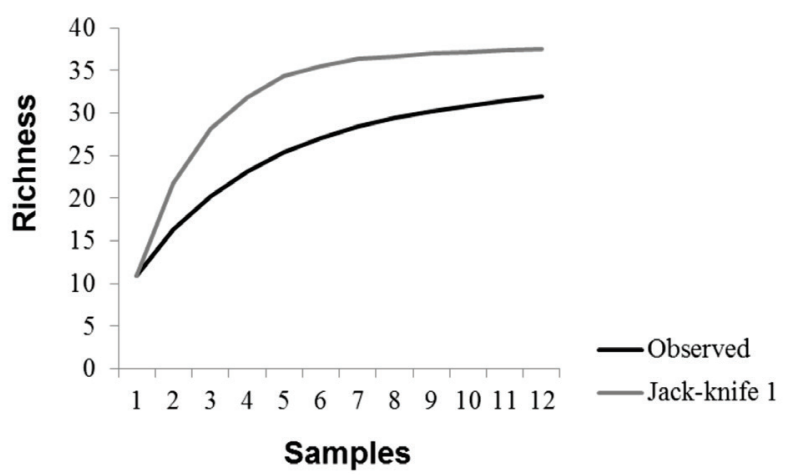

Fig. 1. Collector curve showing the cumulative number (observed) and the estimation of species richness (Jack-Knife 1) of social wasps in the Reserva Biológica Unilavras/Boqueirão, Ingaí, state of Minas Gerais, Brazil.

Only six species were frequent in $50 \%$ or more of the samples. Active search in the Cerrado Field recorded all the six high frequency species in the samples, passion fruit juice three species and sardines two high frequent species (Tab. I). No high frequency species was recorded in the Riparian Forest area (Tab. I).

A total of 18 species were exclusively captured using the active search method, two species were collected only in the passion fruit juice trap and there were no species exclusively related to the sardines (Tab. I). From the 16 species registered in the Riparian Forest, only one was exclusive to this phytophysiognomy. All the other species were also recorded in the Cerrado Field, 16 being exclusive to this area (Tab. I).

The highest richness was collected for the active search (31 species), followed by passion fruit juice (11 species) and sardines (nine species) (Fig. 2). When the species richness in the areas was compared, the Cerrado Field recorded higher species richness (31 species) compared to the Riparian Forest (16 species) (Fig. 3).

Comparing the Shannon-Wiener diversity index $\left(\mathrm{H}^{\prime}\right)$ among the methods, the highest diversity was recorded in the active search method ( $\left.H^{\prime}: 1.1505\right)$, followed by passionfruit-juice $\left(\mathrm{H}^{\prime}: 0.5515\right)$ and sardines the lowest diversity value (H': 0.0269) (Fig. 4). The highest Berger-Parker dominance index was obtained in the sardines (BPD: 0.9905), followed by the passion fruit-juice (BPD: 0.6382) and active search (BPD: 0.2958) (Fig. 5).

The Shannon-Wiener diversity index $\left(\mathrm{H}^{\prime}\right)$ showed higher diversity in the Cerrado Field ( $\mathrm{H}^{\prime}$ : 0.2483) compared to the Riparian Forest (H': 0.0479) (Fig. 6). According to the results obtained through the Berger- 
Tab. I. List of social wasps species recorded in the Reserva Biológica Unilavras/Boqueirão, southern of the state of Minas Gerais, Brazil. Total abundance and frequencies relative to the total of 12 samples, the methods and areas where the species were sampled and seasons of the recorded (S, sardines; PF, passion fruit juice; AS, active search; CF, Cerrado Field; RF, Riparian Forest).

\begin{tabular}{|c|c|c|c|c|c|c|c|c|c|c|c|}
\hline \multirow[b]{3}{*}{ Species } & \multirow[b]{3}{*}{ Abundance } & \multicolumn{6}{|c|}{ Frequency $(\%)$} & \multicolumn{4}{|c|}{ Seasonality } \\
\hline & & \multicolumn{3}{|c|}{ Cerrado Field } & \multicolumn{3}{|c|}{ Riparian Forest } & \multicolumn{2}{|c|}{ Dry } & \multicolumn{2}{|c|}{ Wet } \\
\hline & & $\mathrm{S}$ & $\mathrm{PF}$ & AS & $\mathrm{S}$ & $\mathrm{PF}$ & AS & $\mathrm{CF}$ & RF & $\mathrm{CF}$ & RF \\
\hline Apoica (Apoica) gelida Van der Vecth, 1972 & 21 & - & 33.3 & - & - & 8.3 & - & 1 & - & 19 & 1 \\
\hline Brachygastra lecheguana (Latreille, 1824) & 9 & 8.3 & - & 25 & 8.3 & - & - & 1 & 1 & 7 & - \\
\hline $\begin{array}{l}\text { Mischocyttarus (Haplometrobius) confusus } \\
\text { Zikan, } 1935\end{array}$ & 6 & - & - & 8.3 & - & - & 25 & - & - & 2 & 4 \\
\hline $\begin{array}{l}\text { Mischocyttarus (Haplometrobius) tricolor } \\
\text { Richards, } 1945\end{array}$ & 1 & - & - & 8.3 & - & - & - & - & - & 1 & - \\
\hline $\begin{array}{l}\text { Mischocyttarus (Kappa) atramentarius } \\
\text { Zikan, } 1949\end{array}$ & 2 & - & - & 16.6 & - & - & - & - & - & 2 & - \\
\hline Mischocyttarus (Kappa) latior (Fox, 1898) & 1 & - & - & 8.3 & - & - & - & 1 & - & - & - \\
\hline $\begin{array}{l}\text { Mischocyttarus (Mischocyttarus) drewseni } \\
\text { de Saussure, } 1954\end{array}$ & 15 & - & - & 50 & - & - & 8.3 & 5 & - & 9 & 1 \\
\hline $\begin{array}{l}\text { Mischocyttarus (Mischocyttarus) } \\
\text { rotundicollis (Cameron, 1912) }\end{array}$ & 28 & - & - & 58.3 & - & - & - & 11 & - & 17 & - \\
\hline $\begin{array}{l}\text { Mischocyttarus (Monocyttarus) marginatus } \\
\text { (Fox, 1898) }\end{array}$ & 1 & - & 8.3 & - & - & - & - & - & - & 1 & - \\
\hline $\begin{array}{l}\text { Mischocyttarus (Monocyttarus) cassununga } \\
\text { R. von Ihering, } 1903\end{array}$ & 4 & - & - & 25 & - & - & - & 1 & - & 2 & 1 \\
\hline Parachartergus fraternus (Gribodo, 1892) & 6 & - & 25 & 16.6 & - & - & 8.3 & 2 & - & 3 & 1 \\
\hline Polistes actaeon Haliday, 1836 & 2 & - & - & 16.6 & - & - & - & 1 & - & 1 & - \\
\hline Polistes billardieri Fabricius, 1804 & 10 & - & 25 & 33.3 & - & - & - & 2 & - & 8 & - \\
\hline Polistes cinerascens de Saussure, 1854 & 5 & - & - & 16.6 & - & - & 8.3 & - & - & 2 & 3 \\
\hline Polistes ferreri de Saussure, 1853 & 56 & - & 100 & 75 & - & - & - & 13 & - & 43 & - \\
\hline Polistes geminatus (Fox, 1898) & 1 & - & - & 8.3 & - & - & - & - & - & 1 & - \\
\hline Polistes lanio (Fabricius, 1775) & 2 & - & - & 16.6 & - & - & - & 2 & - & - & - \\
\hline Polistes subsericeus de Saussure, 1854 & 7 & - & - & 41.6 & - & - & - & 1 & - & 6 & - \\
\hline Polistes versicolor (Olivier, 1791) & 4 & - & - & 16.6 & - & - & 8.3 & - & - & 3 & 1 \\
\hline Polistes sp. & 2 & - & - & 8.3 & - & - & - & - & - & 2 & - \\
\hline $\begin{array}{l}\text { Polybia (Hypopolybia) bifasciata } \\
\text { de Saussure, } 1854\end{array}$ & 7 & - & - & 8.3 & 16.6 & - & - & - & - & 3 & 4 \\
\hline $\begin{array}{l}\text { Polybia (Myrapetra) fastidiosuscula } \\
\text { de Saussure, } 1854\end{array}$ & 6129 & 100 & 100 & 100 & 100 & 100 & 75 & 1049 & 1584 & 2393 & 1102 \\
\hline $\begin{array}{l}\text { Polybia (Myrapetra) occidentalis } \\
\text { (Olivier, 1791) }\end{array}$ & 14 & - & 8.3 & 50 & 8.3 & 16.6 & - & 5 & 3 & 6 & - \\
\hline $\begin{array}{l}\text { Polybia (Myrapetra) paulista } \\
\text { H. von Ihering, } 1896\end{array}$ & 2 & 8.3 & - & 8.3 & - & - & - & 2 & - & - & - \\
\hline $\begin{array}{l}\text { Polybia (Trichotorax) chrysothorax } \\
\text { (Lichtenstein, 1796) }\end{array}$ & 14 & - & 8.3 & - & 8.3 & 33.3 & 16.6 & - & - & 1 & 13 \\
\hline $\begin{array}{l}\text { Polybia (Trichotorax) ignobilis } \\
\text { (Haliday, 1836) }\end{array}$ & 40 & 8.3 & 41.6 & 66.6 & - & - & 8.3 & 18 & - & 21 & 1 \\
\hline $\begin{array}{l}\text { Polybia (Trichotorax) minarun } \\
\text { Ducke, } 1906\end{array}$ & 1 & - & - & - & - & - & 8.3 & - & - & - & 1 \\
\hline $\begin{array}{l}\text { Polybia (Trichotorax) sericea } \\
\text { (Olivier, 1791) }\end{array}$ & 144 & 91.6 & 50 & 91.6 & - & - & - & 46 & - & 98 & - \\
\hline $\begin{array}{l}\text { Protonectarina sylveirae } \\
\text { (de Saussure, 1854) }\end{array}$ & 7 & - & - & 33.3 & - & - & - & 3 & - & 4 & - \\
\hline Protopolybia sedula (de Saussure, 1854) & 10 & - & - & 25 & - & - & 8.3 & - & - & 7 & 3 \\
\hline $\begin{array}{l}\text { Pseudopolybia vespiceps } \\
\text { (de Saussure, } 1864)\end{array}$ & 6 & 8.3 & 8.3 & 8.3 & - & - & 16.6 & 1 & - & 3 & 2 \\
\hline Synoeca cyanea (Fabricius, 1775) & 5 & - & - & 33.3 & - & - & - & 3 & - & 2 & - \\
\hline
\end{tabular}

Parker dominance index, the Riparian Forest (BPD: 0.9853) presented higher dominance than the Cerrado Field (BPD: 0.8975) (Fig. 7).

The Spearman test showed that the temperature $(\mathrm{p}=0.0017, \mathrm{r}=0.8017)$ and rainfall $(\mathrm{p}=0.0129, \mathrm{r}=$ $0.6908)$ had significant and positive correlation with the species richness (Figs 8, 9). The highest richness occurred between September and March. November was the most representative (richness) month, with 18 species recorded. The ANOVA test showed significant variation in richness between dry and wet seasons $(\mathrm{F}(1 ; 10)=18.4091 ; \mathrm{p}=0.0016)$ (Fig. 10). Only three species were not sampled during the wet season. Polybia fastidiosuscula was more abundant in the Riparian Forest during the dry season and in the Cerrado Field during the wet season (Tab. I.). 

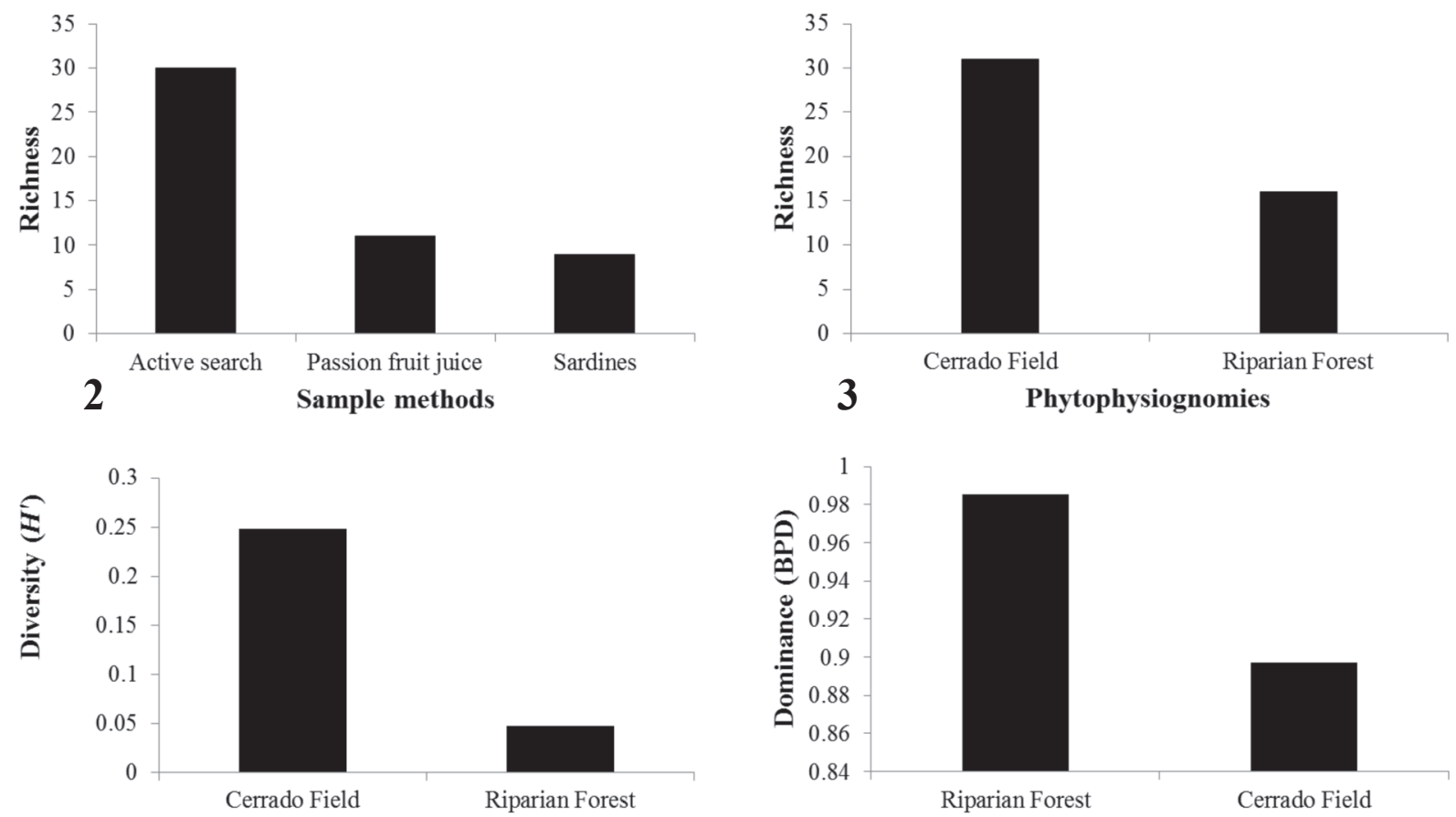

\section{4}

Phytophysiognomies
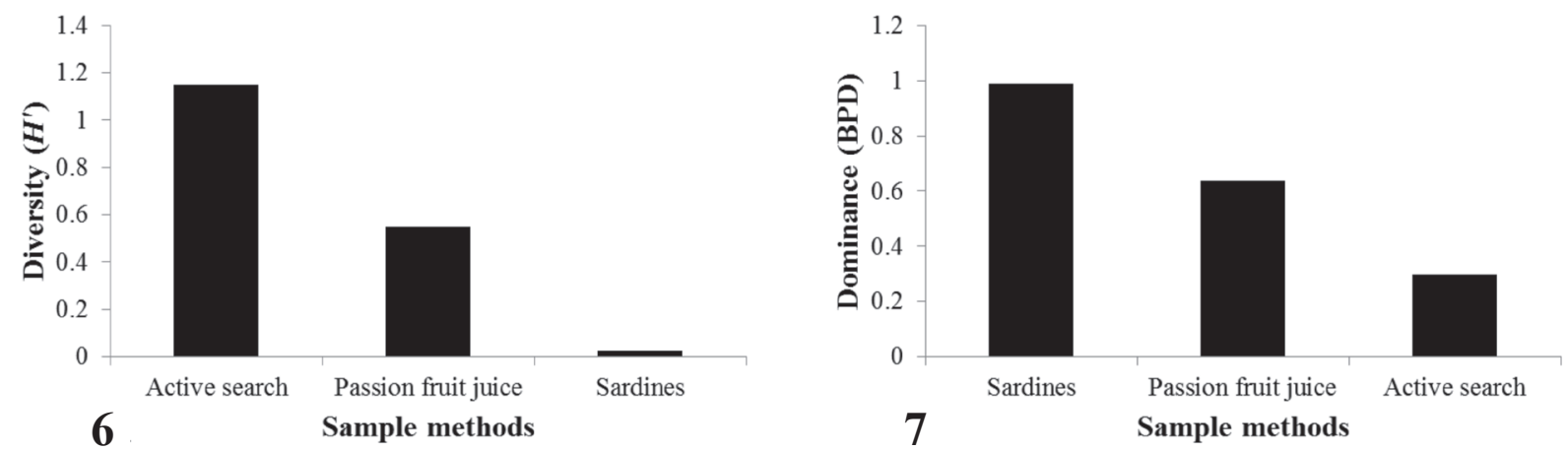

Figs 2-7. Figs 2, 3: species richness of social wasps for the sample methods (2) and phytophysiognomies (3) studied in the Reserva Biológica Unilavras/Boqueirão, Ingaí, state of Minas Gerais, Brazil; the highest richness was recorded to active search and Cerrado Field. Figs 4, 5: 4, Shannon-Wiener diversity index $\left(\mathrm{H}^{\prime}\right)$ and 5, Berger-Parker dominance index (BPD) for the sample methods; the highest diversity was recorded to active search and the highest dominance was recorded to sardines. Figs 6, 7: 6, Shannon-Wiener diversity index (H ') and 7, Berger-Parker dominance index (BPD) for the different phytophysiognomies sampled by the active search and attractive trap methods; the highest diversity was recorded to Cerrado Field and the highest dominance was recorded to Riparian Forest.
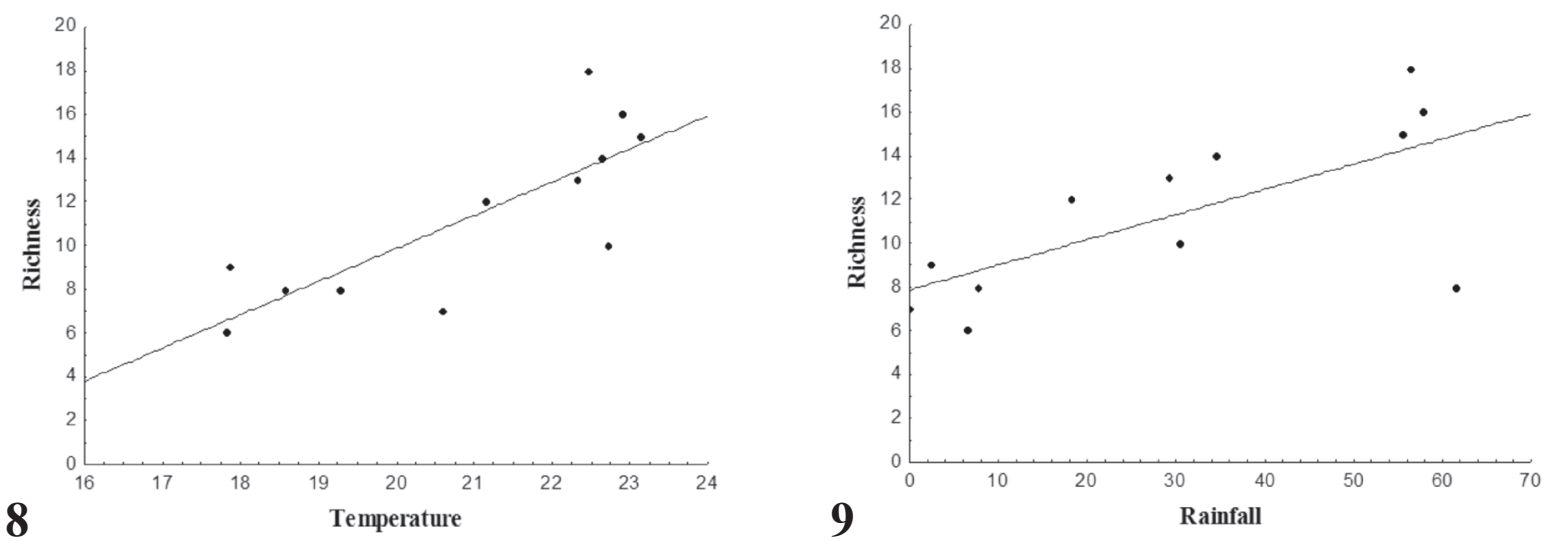

Figs 8, 9. Sperman's Correlation between temperature (8) and rainfall (9) with the richness of social wasps in the Reserva Biologica Unilavras/ Boqueirão, Ingaí, state of Minas Gerais, Brazil. The species richness of social wasps was positively related to temperature $(\mathrm{r}=0.8017 ; \mathrm{p}=0.0017)$ and rainfall $(\mathrm{r}=0.6908 ; \mathrm{p}=0.0129)$. 


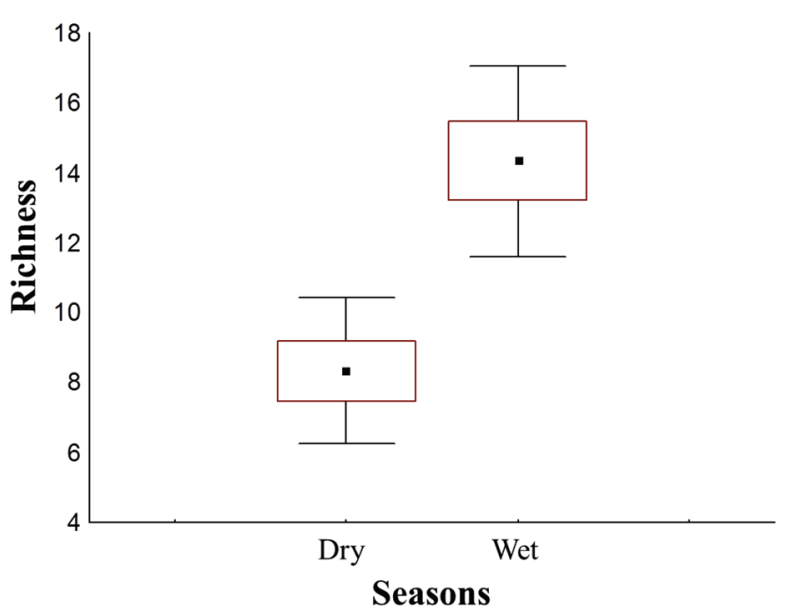

Fig. 10. Box-plot of the ANOVA test showing variation in richness between dry and wet seasons $(F(1 ; 10)=18.4091 ; p=0.0016)$. Mean; Mean+/-Standard error; Mean+/-Standard deviation.

\section{DISCUSSION}

This is the first study performed in southern of the state of Minas Gerais and the great local diversity of social wasps is evident when comparing the results in studies conducted in other regions of the state.

ElPino-CAmpos et al. (2007) registered 29 species distributed in 10 genera in Cerrado areas in the town of Uberlândia, located in the region known as "Triângulo Mineiro". Although this study had been conducted in an area seven times larger than the area of the Reserva Biológica Unilavras/Boqueirão, they recorded a lower richness of social wasps.

Prezoto \& Clemente (2010) registered 23 species belonging to 10 genera in their study in Ibitipoca State Park (Parque Estadual do Ibitipoca - PEIB), located in the Serra de Ibitipoca, southeastern of state. The PEIB has an area ten times larger than the area studied here and it also contains a fragment of the Atlantic Forest biome, which is expected to hold a great diversity of organisms.

Souza et al. (2010) sampled 32 species in the "Serra de São José" in the municipality of Tiradentes. The region called as "Campo das Vertentes" represents approximately 41\% (2.050 ha) of the São José environmental protection area (Área de Proteção Ambiental de São José), thus approximately 13 times larger than the Reserva Biológica Unilavras/Boqueirão.

The highest number of species recorded in a single study area was registered in the municipality of Barroso, in a forest known as "Mata do Baú", with total area of approximately $4 \mathrm{~km}^{2}$ (SouzA \& Prezoto, 2006). Thirty eight species of 10 genera were sampled. The "Mata do Baú" has twice the area of the Reserva Biológica Unilavras/Boqueirão.

These comparisons confirm the relevance of the high diversity of social wasps found in the present study. This area is almost entirely surrounded by pasture and agricultural areas, which could make the study area one of the few refuges where these organisms could survive without being affected by pesticides (used in most of the surroundings).

Most species recorded showed low sample frequency. Of the 32 species sampled, 16 species belong to Mischocyttarini and Polistini tribes. Thus, the presence of several species of these tribes can explain the low frequency in samples, since these tribes have colonies that rarely exceed a few tens of individuals (CARPENTER \& Marques, 2001). So, low abundance species may be rare in the samples.

The lower richness and diversity recorded in the Riparian Forest compared to the Cerrado Field and the low species frequency in the samples may be due to two factors: presence of dominant species and the difficulty of sampling by active search in this environment. Polybia fastidiosuscula showed high dominance $(98.5 \%)$ in this phytophysiognomy and it was the only one frequent in the samples. Furthermore, the fact that the Riparian Forest is made up of large trees (some over 20 meters tall), decreases the light incidence into the area. This lack of luminosity makes visual sampling by active search method difficult and could result in an underestimation of the area richness. Lower diversity rates in relation to the difficulties posed for sampling in areas of dense vegetation have already been reported (Silveira, 2002; Souza \& Prezoto, 2006). Furthermore, active search has been described as one of the best methods to capture social wasps, since it enables the sampling of species with cryptic nests as well as foraging individuals, searching for resources (food and nest building) (Silveira, 2002). Thus, because the method that has been described as that which recorded the highest diversity of species is hindered, less diversity sampled in the study area is expected.

Another factor that influences the species diversity of the areas is that the species nesting habitat is not necessarily the habitat where it forages. DINIZ \& Kitayama (1994) showed that social wasps have a preference for nesting in moist habitats because of the availability of water throughout the year and greater nest protection, but prefers to forage in drier habitats. Thus, although there could be more species colonies in the Riparian Forest, more species were recorded in the Cerrado Field.

Climatic factors may be decisive for the intensity of social wasp foraging activity, as has been demonstrated in several studies (РRezoto et al. 1994; Giannotti et al., 1995; Andrade \& Prezoto, 2001; Elpino-Campos et al., 2007; Gomes \& Noll, 2009, AuAD et al., 2010). The temperature has been reported as the environmental factor that most influences the foraging activity of social wasps and as observed in this study, it is under the highest temperatures that a greater number of workers leave the colony to forage, probably because high temperatures increase the need for water by the colony (Lima \& Prezoto, 2003; Cavenazzi \& Noll, 2011). Rainfall, 
as well as temperature, also influenced the species richness. These environmental factors probably have more influence in field areas than in forest areas. Thus, the variation in the correlation of climatic factors with the richness and foraging activity of species may be more related to the combination of climatic factors and physical environment than only to the climatic factors.

As discussed above, the temperature and rainfall increases the foraging activity. So, as seen in this study, more species and more individuals will be foraging during the hot and humid season (wet season). Higher species richness and individuals in the wet season has been recorded in other studies (Diniz \& Kitayama, 1998; Elpino-CAmpos et al., 2007; AuAD et al., 2010). The higher abundance of Polybia fastidiosuscula in the Riparian Forest during the dry season shows the importance of this environment as a more favorable habitat for colony maintenance during the dry season (Diniz \& KitAYAMA , 1998).

The study area showed a great diversity of social wasps of the Cerrado biome of the state of Minas Gerais, recording widely distributed species such as rare species, for example Polistes geminatus and Mischocyttarus confusus, which indicates the quality and the potential of the area for future research.

Acknowledgements. To the Centro Universitário de Lavras (Unilavras) and FAPEMIG for the financial support. To Dr. Marcos Magalhães de Souza and Dr. Orlando Tobias Silveira (Museu Paraense Emílio Goeldi), for the help in the identification of the social wasps. Thanks to two anonymous referees for their critical reading of a previous draft.

\section{REFERENCES}

Andrade, F. R. \& Prezoto, F. 2001. Horários de atividade forrageadora e material coletado por Polistes ferreri Saussure, 1853 (Hymenoptera, Vespidae), nas diferentes fases de seu ciclo biológico. Revista Brasileira de Zoociências 3(1):117-128.

Aund, A. M.; Carvalho, C. A.; Clemente, M. A. \& Prezoto, F. 2010. Diversity of Social Wasps in a Silvipastoral System. Sociobiology 55:627-636.

Canevazzi, N. C. S. \& Noll, F. B. 2011. Environmental Factors Influencing Foraging Activity in the Social Wasp Polybia paulista (Hymenoptera: Vespidae: Epiponini). Psyche: A Journal of Entomology 2011:1-8.

Carpenter, J. M. 1982. The phylogenetic relationships and natural classification of the Vespoidea (Hymenoptera). Systematic Entomology 7:11-38.

2004. Synonymy of the Genus Marimbonda Richards, 1978, with Leipomeles Möbius, 1856 (Hymenoptera: Vespidae; Polistinae), and a new key to the genera of paper wasps of the New World. American Museum Novitates 3465:1-16.

Carpenter, J. M. \& Marques, O. M. 2001. Contribuição ao estudo dos vespídeos do Brasil (Insecta, Hymenoptera, Vespoidea, Vespidae). Cruz das Almas, Universidade Federal da Bahia Publicações digitais. $147 \mathrm{p}$

Cullen Jr, L.; Rudran, R. \& Valladares-Padua, C. orgs. 2003. Métodos de Estudos em Biologia da Conservação e Manejo da Vida Silvestre. Curitiba, Editora da UFPR. 667p.

Diniz, I. R. \& Kitayama, K. 1994. Colony densities and preferences for nest habitats of some social wasps in Mato Grosso State, Brasil
(Hymenoptera: Vespidae). Journal of Hymenoptera Research 3:133-143.

1998. Seasonality of vespid species (Hymenoptera: Vespidae) in a central Brazilian cerrado. Revista de Biología Tropical 46:(1)109-114

Elpino-Campos, A.; Del-Claro, K. \& Prezoto, F. 2007. Diversity of Social Wasps (Hymenoptera: Vespidae) in Cerrado fragments of Uberlândia, Minas Gerais State, Brazil. Neotropical Entomology 36(5):685-692.

Giannotti, E.; Prezoto, F. \& Machado, V. L. L. 1995. Foraging activity of Polistes lanio lanio (Fabr.) (Hymenoptera, Vespidae). Anais da Sociedade Entomológica do Brasil 24(3):455-463.

Gomes, B. \& Noll, F. B. 2009. Diversity of social wasps (Hymenoptera, Vespidae, Polistinae) in three fragments of semideciduous seasonal forest in the northwest of São Paulo State, Brazil. Revista Brasileira de Entomologia 53(3):428-431.

Lima, M. A. P., Lima , J. R. \& Prezoto , F. 2000. Levantamento dos gêneros de vespas sociais (Hymenoptera, Vespidae), flutuação das colônias e hábitos de nidificação no campus da UFJF, Juiz de Fora, MG. Revista Brasileira de Zoociências 2(1):69-80.

Lima, M. A. P. \& Prezoto, F. 2003. Foraging activity rhythm in the neotropical swarm-founding wasp Polybia platycephala sylvestris (Hymenoptera: Vespidae) in different seasons of the year. Sociobiology 42(3): 745-752.

O'Donnell, S. 1995. Necrophagy by Neotropical Swarm-Founding Wasps (Hymenoptera: Vespidae, Epiponini). Biotropica 27(1):133-136.

Pereira, G. J. M. \& Volpato, M. M. L. 2005. Levantamento das características bióticas e abióticas da área do Boqueirão. Pro Homine 3:27-34.

Prezoto, F. \& Clemente, M. A. 2010. Vespas sociais do Parque Estadual do Ibitipoca, Minas Gerais, Brasil. MG Biota 3(4)22-32.

Prezoto, F.; Giannotti, E. \& Machado, V. L. L. 1994. Atividade forrageadora e material coletado pela vespa social Polistes similimus Zikán (1951) (Hymenoptera, Vespidae). Insecta 3(1):11-19.

Prezoto, F.; Ribeiro-Júnior, C.; Oliveira, S. A. \& Elisei, T. 2007. Manejo de vespas e marimbondos em ambientes urbanos. In: Pinto, A. S.; Rossi, M. M. \& Salmeron, E. orgs. Manejo de pragas urbanas. Piracicaba, Ed. Piracicaba. p. 125-130.

Rodrigues, W. C. 2007. DivEs - Diversidade de Espécies - Guia do Usuário. Seropédica, Entomologistas do Brasil. Disponível em: $<$ http://www.ebras.bio.br/dives/>. Acesso em: 10.08.2010.

Santos, G. M. M.; Bichara Filho, C. C.; Resende, J. J.; Cruz, J. D. \&. Marques, O. M. 2007. Diversity and Community Structure of Social Wasps (Hymenoptera:Vespidae) in three Ecosystems in Itaparica Island, Bahia State, Brazil. Neotropical Entomology 36(2): $180-185$

Silva, S. S. \& Silveira, O. T. 2009. Vespas sociais (Hymenoptera, Vespidae, Polistinae) de floresta pluvial Amazônica de terra firme em Caxiuanã, Melgaço, Pará. Iheringia, Série Zoologia 99(3):317-323.

Silveira, O. T. 2002. Surveying Neotropical Social Wasps. An evaluation of methods in the "Ferreira Penna" research station (ECFPN), in Caxiuanã, PA, Brazil (Hym., Vespidae, Polistinae). Papéis Avulsos de Zoologia 42(12):299-323.

Silveira, O. T.; Costa Neto, S. V. \& Silveira, O. F. M. 2008. Social wasps of two wetland ecosystems in Brazilian Amazonia (Hymenoptera, Vespidae, Polistinae). Acta Amazonica 38(2):333-344.

Silveira, O. T.; Esposito, M. C.; Santos JR, J. N. \& Gemaque JR, F. E. 2005. Social wasps and bees captured in carrion traps in a rainforest in Brazil. Entomological Science 8:33-39.

Souza, M. M. DE \& Prezoto, F. 2006. Diversity of social wasps (Hymenoptera: Vespidae) in semideciduous forest and cerrado (Savanna) regions in Brazil. Sociobiology 47(1):135-147.

Souza, M. M.; Silva, M. J.; Silva, M. A. \& Assis, N. R. G. 2010. Ecologia de vespas sociais (Hymenoptera, Vespidae) no Campo Rupestre na Área de Proteção Ambiental, APA, São José, Tiradentes, MG. MG Biota 3(2):15-30. 